\title{
Exploratory Investigation for Improvement of the External Quality Assessment Scheme for Transfusion Medicine
}

\author{
John Jeongseok Yang ${ }^{1 \oplus}$, Jin Seok Kim ${ }^{1 \oplus}$, Yousun Chung ${ }^{2 \oplus}$, Hyungsuk Kim ${ }^{3 \oplus}$, Dae-Hyun Ko ${ }^{1 \oplus}$, \\ Sang-Hyun Hwang ${ }^{1 \oplus}$, and Heung-Bum $\mathrm{Oh}^{1 \oplus}$ \\ ${ }^{1}$ Department of Laboratory Medicine, Asan Medical Center, University of Ulsan College of Medicine; ${ }^{2}$ Department of Laboratory \\ Medicine, Kangdong Sacred Heart Hospital; ${ }^{2}$ Department of Laboratory Medicine, Seoul National University Hospital, Seoul, \\ Korea
}

\section{Corresponding author:}

Dae-Hyun Ko

Department of Laboratory Medicine, Asan Medical Center, University of Ulsan College of Medicine, 88 Olympic-ro 43gil, Songpa-gu, Seoul 05505, Korea Tel +82-2-3010-4504

Fax +82-2-478-0884

E-mail daehyuni1118@amc.seoul.kr

Received: November 27, 2020

Revised: December 21, 2020

Accepted: January 5, 2021

This is an Open Access article distributed under the terms of the Creative Commons Attribution Non-Commercial License (http://creativecommons.org/licenses/ by-nc/4.0) which permits unrestricted non-commercial use, distribution, and reproduction in any medium, provided the original work is properly cited.
Background: This study summarizes a survey conducted to improve and expand the external quality assessment (EQA) scheme for transfusion in Korea.

Methods: The EQA items provided by the College of American Pathologists, Royal College of Pathologists of Australasia, National External Quality Assessment Service, and German program were explored. A commercially operated EQA program was also included in the survey.

Results: Items not included in the Korean EQA programs included extended antigen typing, electronic cross-matching, eluate survey, and fetal red cell detection. Granulocyte- and platelet-related testing was also not covered by the Korean program. There were issues regarding establishing the criteria for acceptable ranges and manufacturing of EQA materials.

Conclusions: We successfully conducted a survey for the improvement and expansion of EQA for transfusion medicine. A pilot project for extended antigen typing is expected to be implemented in 2021, and ongoing expansion will continue in the following years.

(Lab Med Qual Assur 2021;43:19-24)

Key Words Transfusion medicine, Proficiency testing, External quality assessment

\section{서론}

대한임상검사정도관리협회에서는 2016년부터 차세대 정도관 리 프로그램을 개발, 대상항목을 300 여 종 이상으로 대폭 확장하 였다. 그러나 수혈의학 검사분야에서는 현재 일반수혈검사, 수혈 항원검사(특수), 수혈항체검사(일반), 수혈항체검사(특수) 총 4가 지 분야에서 10종의 항목에 대해서만 신빙도조사사업이 시행되고 있다(Table 1). 이는 수혈의학분야의 검사종류가 다양하지 않기 때문이지만 외국 신빙도조사사업 프로그램에는 시행되고 있으나 국내 신빙도조사사업 프로그램에서 시행하지 않는 일부 검사항목
도 존재한다.

이에 본 연구에서는 국내외 자료조사 및 전문가 자문을 토대로 국내 수혈의학분야 신빙도조사사업 개선을 위한 기초 자료 조사를 시행하였다.

\section{재료 및 방법}

\section{1. 국외 신빙도조사사업 프로그램 조사}

국외 신빙도조사사업 프로그램 조사를 위하여 미국(The College of American Pathologists, CAP), 호주(The Royal 
Table 1. Current test items for proficiency testing in Korea

\begin{tabular}{|c|c|c|c|}
\hline Major category & Minor category & Test name & $\begin{array}{l}\text { No. of } \\
\text { trials } \\
\text { per year }\end{array}$ \\
\hline \multirow[t]{10}{*}{ Transfusion medicine } & General transfusion testing & Blood crossmatching & 2 \\
\hline & & ABO typing & 2 \\
\hline & & RhD typing & 2 \\
\hline & Transfusion antigen testing, special & ABO subtyping & 2 \\
\hline & & Rh CcEe antigen test & 2 \\
\hline & & Weak D test & 2 \\
\hline & Transfusion antibody testing, general & Unexpected antibody, screening & 2 \\
\hline & & Direct anti-human globulin test & 2 \\
\hline & Transfusion antibody testing, special & Unexpected antibody, identification & 2 \\
\hline & & $\mathrm{ABO}$ antibody titration & 2 \\
\hline Molecular genetics & Other genetic testing & ABO genotyping & 2 \\
\hline
\end{tabular}

College of Pathologists of Australasia, RCPA), 독일(INSTAND e.V.) 및 영국(UK National External Quality Assessment Service, UK NEQAS) 프로그램의 자료를 조사하였다. 각 나라별 신빙도조사사업 프로그램 중 수혈의학분야 관련 검사항목에 대하 여 자료를 수집하였다. 그리고 민간기업인 Bio-Rad사(Bio-Rad Laboratories, Hercules, CA, USA)에서 시행하는 신빙도조사사 업(Bio-Rad External Quality Assurance Services, Bio-Rad Laboratories) 프로그램에 포함된 수혈의학 관련 검사항목 자료 를 수집하였다. 수집된 자료를 국내 신빙도조사사업 프로그램과 비교하여 검사항목 및 판정기준 등에 대한 비교를 실시하였다[1].

\section{2. 국내 신빙도조사물질 개선점 모색}

2016년 이후 시행되고 있는 차세대 신빙도조사사업 프로그램 에서 사용하고 있는 신빙도조사물질에 대하여 물질 제조방법 및 그에 대한 문제점을 파악하고 개선점을 모색하였다.

\section{3. 전문가 의견 수렴}

대한수혈학회 산하 면역혈액학위원회 운영위원(10명)에게 국 내외 신빙도조사사업 프로그램 항목을 안내하고 국내 신빙도조사 사업 프로그램에 추가를 원하거나 필요하다고 생각되는 항목에 대 해 온라인으로 의견 수렴을 실시하였다.

\section{결과}

\section{1. 국외 신빙도조사사업 프로그램}

국외 신빙도조사사업 프로그램에서 수혈의학 관련 검사항목
을 Table 2에 요약하였다. 국내에서 시행하고 있지 않은 항목 으로 Kell 등의 extended antigen typing, electronic crossmatching, eluate survey, fetal red cell detection 등이 있음 을 확인하였다. 그 외 특수검사로 granulocyte/platelet 관련 검 사들(granulocyte genotyping, granulocyte immunology, platelet genotyping, platelet crossmatching 등)이 국외에서 시행되고 있지만 국내 임상검사실에서는 거의 시행하고 있지 않거 나 보험급여로 등재되어 있지 않은 항목들이 있었다.

또한 CAP에서만 제공하고 있는 프로그램인 Educational Challenge는 각종 임상적 상황을 제시하고 이에 대하여 적절한 해석 및 대처방안을 묻는 프로그램도 제공하고 있었다. 이에 해당 하는 내용으로 수혈부작용, 면역혈액학적 기본지식 등 수혈의학의 다양한 분야가 다뤄지고 있었다.

독일의 INSTAND e.V.에서는 다른 나라에서 제공하고 있지 않 는 과립구 유전형 검사 및 항체검사, 그리고 다양한 적혈구 항원에 대한 유전형 검사(ABO, MNS, RHD, RHD-deletion, RHCE, LU, KEL [K/k, Kp, Js], FY, JK, DI, YT, DO, CO, LW, KN, VEL)에 대 한 프로그램을 제공하는 점이 주목할 만하였다.

판정기준에 있어서 유의할 부분은 혈액형 항원에 대한 항체역 가검사에서 국내 신빙도조사사업에서는 반정량검사 판정기준인 최빈값 \pm 1 역가 이내를 acceptable로 판정하지만, CAP의 동일한 검사 판정기준은 최빈값 \pm 2 역가 이내를 acceptable로 판정한다 는 점에서 차이를 나타냈다.

판정기준에 대해서는 정보 접근 가능한 CAP의 판정기준과 비 교하여 Table 3에 나타냈다. 국내 신빙도조사사업의 경우 대원칙 에 의거하여 intended response를 기준으로 하되, 참여기관의 


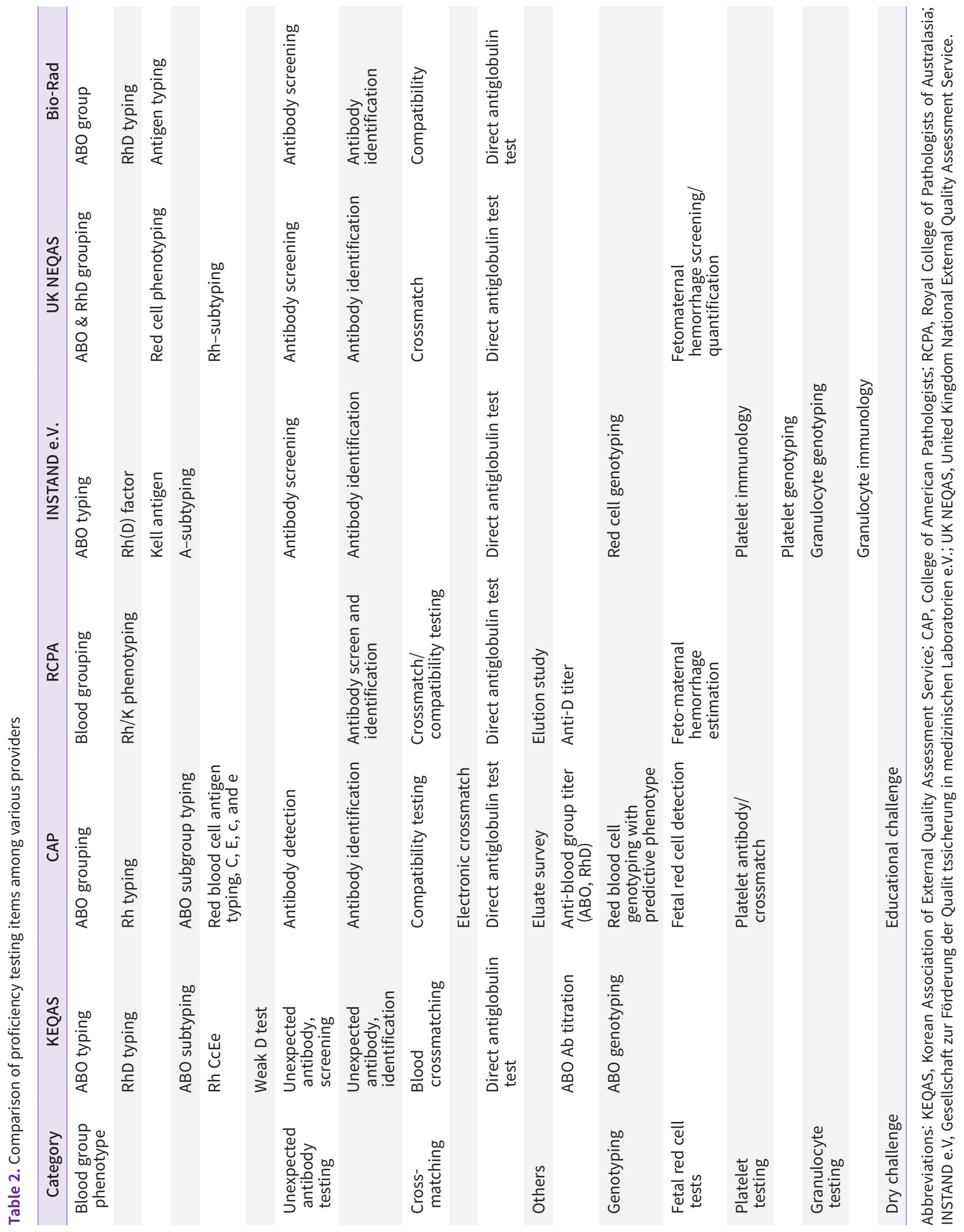


Table 3. Comparison of acceptable criteria between KEQAS and CAP

\begin{tabular}{lll}
\hline \multicolumn{1}{c}{ Variable } & \multicolumn{1}{c}{ KEQAS } & CAP \\
\hline ABO typing & Intended response (80\% consensus) & $95 \%$ participant or 100\% referee consensus \\
RhD typing & Intended response (80\% consensus) & $95 \%$ participant or $100 \%$ referee consensus \\
ABO subgroup typing & Intended response (80\% consensus) & No consensus criteria \\
RhCcEe typing & Intended response (80\% consensus) & No consensus criteria \\
Unexpected antibody screening & Intended response (80\% consensus) & $95 \%$ participant or $95 \%$ referee consensus \\
Unexpected antibody identification & Intended response (80\% consensus) & $95 \%$ participant or $95 \%$ referee consensus \\
Crossmatch & Intended response (80\% consensus) & $95 \%$ participant or $100 \%$ referee consensus \\
Direct antiglobulin test & Intended response (80\% consensus) & $90 \%$ participant consensus \\
ABO antibody titration & Mode \pm 1 titers & Mode \pm 2 titers \\
\hline
\end{tabular}

Abbreviations: KEQAS, Korean Association of External Quality Assessment Service; CAP, College of American Pathologists.

Table 4. Candidate items for expansion of proficiency testing in transfusion medicine

\begin{tabular}{cll}
\hline Major category & \multicolumn{1}{c}{ Minor category } & \multicolumn{1}{c}{ Test name } \\
\hline Transfusion medicine & Transfusion antigen testing, special & Special antigen test (Kidd, Duffy, Lewis, etc.) \\
& Transfusion antibody testing, special & Rh antibody titration \\
Molecular genetics & Other genetic testing & Dithiothreitol treatment for eliminating drug interferences \\
\hline
\end{tabular}

$80 \%$ 이상에서 합의가 이루어져야 판정을 내리나 CAP의 경우 검 사항목별로 약간씩 차이가 있었다. 또 CAP에서는 응집강도나 $\mathrm{ABO}$ 아형, Rh CcEe typing 등에 대해서는 참여기관들의 분포만 제시 하고 판정은 내리지 않는 것이 국내 프로그램과 차이가 있었다.

\section{2. 국내 신빙도조사물질의 제조현황 및 문제점}

국내의 수혈의학분야에서는 신빙도조사물질을 거의 전적으로 자가제조물질을 이용하여 제조하여 왔다. 혈액형 검사물질은 공급 혈액원에서 폐기 예정인 농축적혈구 제제와 신선동결혈장을 혼합, 적정량의 보존제를 첨가 후 혼합하여 분주하는 방법으로 제조하였 다. 비예기항체 선별 및 동정검사용 검체는 폐기 예정인 신선동결 혈장에 상용화된 항혈청을 첨가하여 혼합 후 분주하는 방식으로 제조하였다. 그리고 $\mathrm{ABO}$ 아형 및 $\mathrm{RhD}$ 변이형 검체의 경우에는 폐 기 예정인 농축적혈구 제제에 신선동결혈장을 혼합하여 제조하였 다. 이러한 물질 제조방식의 경우, 특히 혈액형 아형 및 $\mathrm{RhD}$ 음성 검체가 신빙도조사물질 제조기간에 얻을 수 없는 경우에는 원하는 혈액형을 가진 정도관리물질을 제조하는 데에 어려움이 있었다.

\section{3. 전문가 의견 수렴}

국내 전문가 의견 수렴 결과, 국내에서 추가적으로 실시하기 를 원하는 검사항목을 Table 4에 정리하여 나타냈다. 대개 국외 신빙도조사사업에서 시행하고 있는 항목이었고, DTT (dithio-
threitol)/Rh genotyping은 국외 신빙도조사사업에서도 시행하 고 있지 않은 항목이었다. 기타 의견으로 추가적인 검사항목은 아 니지만 비예기항체 선별검사에서 Diego 항체를 포함하는 검체를 사 용한 신빙도조사물질을 제조 필요성에 대한 의견도 있었다.

\section{고찰}

본 연구에서는 국내 신빙도조사사업 확장을 위하여 국내외 수 혈의학분야 신빙도조사사업 프로그램을 조사하고, 관련 전문가 의 견을 수렴하였다. 국내 신빙도조사사업 프로그램에 포함되어 있지 않은 검사항목에 대한 많은 의견이 있었다.

다발성 골수종의 치료제로 쓰이는 Daratumumab (Darzalex; Johnson \& Johnson, New Brunswick, NJ, USA)은 항-CD38 항체로, 형질세포의 표면에 발현하는 CD38을 표적으로 하는 약이 며 현재 임상에서 널리 쓰이고 있다[2]. 그러나 CD38은 림프구 이 외에 적혈구 표면에서도 발현하여 Daratumumab이 적혈구 관련 수혈 전 검사에 간섭을 일으킴이 잘 알려져 있다[3]. 이러한 약물 간섭은 DTT로 처리한 적혈구를 사용하면 제거되어, 현재 국내에 서도 많은 의료기관에서 이러한 처리를 시행하고 있다[4,5]. 하지 만 이에 대한 정도관리는 아직 이루어지고 있지 않아 새로운 신빙 도조사 프로그램으로 이러한 약물간섭 처리를 추가하자는 의견도 있었다. 항-CD38 항체 이외에도 CD47 표적치료제 등의 경우에도 
이러한 간섭을 일으키는 것이 알려져 있고[6], 향후 유사한 약물제 제들이 계속 도입될 것으로 예상되므로 향후 이에 대한 준비도 필 요할 것으로 생각된다.

독일 프로그램에서 특이한 점은 $\mathrm{ABO}, \mathrm{Rh}$ 뿐만 아니라 10 여 개 가 넘는 혈액형 군에 대한 유전형 검사에 대한 신빙도조사 프로그 램을 운영하고 있다는 점이었다. 이는 몇 가지 상품화된 유전형 검 사키트를 위한 프로그램으로 생각된다[7,8]. 일반적으로는 $\mathrm{ABO} /$ $\mathrm{RhD}$ 이외의 혈액형에 대한 검사는 필요하지 않지만 일부 만성적 으로 적혈구 수혈이 예상되는 환자들에 대해 여러 혈액형 군의 혈 액형을 미리 확인하여 이에 맞춘 적혈구 수혈을 시행함으로써 감 작의 가능성을 미리 예방하는 전략을 취할 수 있다[9,10]. 대표적 으로 이에 해당되는 질환은 지중해빈혈이나 겸상적혈구 빈혈같은 헤모글로빈병증이며, 해당 질환들의 치료 가이드라인에서 이러한 extended antigen matched transfusion을 권장하고 있다[11]. 국내에서는 이러한 질환들이 거의 없는 것으로 알려져 extended antigen matched transfusion에 대하여 관심이 없었으나 향후 국내에서도 인종의 다양성이 증대함에 따라 해당 질환 환자들이 늘어날 것으로 예상된다[12]. 또한 CD38, CD47 등을 목표로 하는 치료제 사용의 경우에도 미리 extended antigen typing을 이용 한 수혈을 시도하는 움직임도 있다[13]. 따라서 선제적으로 이러 한 extended antigen typing에 대한 관리 프로그램도 필요할 것 으로 생각된다.

또한 독일에서 시행하고 있는 신빙도조사사업으로 과립구 유 전형 및 항체검사가 있었다. 과립구 항체는 수혈 관련 급성폐손상 (transfusion-related acute lung injury) 및 신생아동종면역호 중구감소증(neonatal alloimmune neutropenia)의 주요 원인 으로 알려져 있으나 아직 국내에서는 임상검사로서 사용되고 있지 않거나 보험급여로 등재되지 않은 항목도 다수 포함되어 있었다. 오히려 수혈부작용 원인조사를 위하여 환자가 아닌 공여자 혈액에 서 항체검사를 시행하는 경우가 있으며 국내에서도 질병관리연구 용역사업으로 과립구 항체검사가 막 시작되었다. 향후 과립구 유 전형 검사까지 확대 시행될 예정으로, 해당 항목들이 국내 신빙도 조사사업에 포함될 것인가에 대해서는 면밀한 검토가 필요할 것으 로 생각된다.

수혈의학분야 신빙도조사물질은 전적으로 자가제조물질을 이 용하고 있기 때문에 혈액형 아형 및 $\mathrm{RhD}$ 변이형 검체의 획득이 어 려운 경우가 많았다는 점을 생각하면 신빙도조사사업 프로그램의 항목 확대는 제한적일 수밖에 없다. 혈액형 아형처럼 구하기 어려 운 혈액의 경우 연중 모집하여 동결보관이 가능한 기관의 도움을 받아 동결보관하였다가 추후 정도관리사업에 활용하는 방법을 고 려할 수 있을 것이다.

추가적인 의견으로 판정기준에 있어서 차이를 나타낸 점이 지
적되었다. 현재 국내 신빙도조사사업의 반정량검사의 평가기준 은 최빈값 \pm 1 grade로 규정되어 있고, 이에 따라 혈액형항원 항 체역가검사도 같은 판정기준을 따르고 있다. 그러나 혈액형 항원 항체는 CAP에서 최빈값 \pm 2 titer를 acceptable로 판정한다는 점 에서 차이가 있었다. 이는 혈액형 항원에 대한 항체역가검사가 표 준화가 되지 않고 검사실 간 차이가 크게 나타날 수 있다는 점을 감안해 결정된 판정기준 때문이라고 생각된다[14]. 역가검사의 특성을 감안해 geometric mean $(\mathrm{GM}) \pm$ geometric standard deviation (GSD)을 사용한 simulation study 결과에 따르면 $\mathrm{CAP}$ 에서 적용하고 있는 최빈값 \pm 2 titer 기준은 $\mathrm{GM} \pm 2 \mathrm{GSD}$ 와 유사한 수준의 분포를 보였다[15]. 국내 신빙도조사사업 정량평가 의 기준이 평균 $\pm 3 S \mathrm{SD}$ 임을 감안할 때에 현행 anti-A/B titer검사의 평가기준은 지나치게 좁은 것으로 생각되어, 향후 국내 신빙도조사 사업 결과에 대해 GM을 활용한 방법과 같은 분석이 필요할 것이다. 요약하면, 본 연구는 수혈의학분야 신빙도조사사업 확대를 위 한 기초자료 조사를 시행하였다. 국외의 신빙도조사사업에서 시행 중인 항목들과 비교하였을 때 국내 외부정도관리 프로그램의 수 가 적었고, 국내 검사실의 다양한 요구에 부응할 필요가 있음을 확 인하였다. 이를 바탕으로 2020년도 수혈의학분야 신빙도조사사 업에 추가할 항목 중 antigen typing에 대한 시범사업이 우선적 으로 선정되어 추진 중이며 해당 수혈의학 외부정도관리 프로그램 확장을 위한 시범사업은 2020년도 대한임상검사정도관리협회 학 술연구과제로 선정되어 시행될 예정이다.

\section{감사의 글}

이 논문은 대한임상검사정도관리협회의 2019년 학술연구비 지 원을 받아 시행한 결과를 바탕으로 작성되었다(과제번호: 20192). 적혈구 동결 보관에 도움을 준 세브란스병원 혈액은행 관계자 분들께 감사드린다.

\section{ORCID}

John Jeongseok Yang

https://orcid.org/0000-0002-7739-1009

Jin Seok Kim https://orcid.org/0000-0003-0166-2084

Yousun Chung https://orcid.org/0000-0002-5197-6340

Hyungsuk Kim https://orcid.org/0000-0002-0574-9200

Dae-Hyun Ko https://orcid.org/0000-0002-9781-0928

Sang-Hyun Hwang https://orcid.org/0000-0003-3201-5728

Heung-Bum Oh https://orcid.org/0000-0001-6728-4640 


\section{REFERENCES}

1. Lim YA, Cho HS. Annual report on the external quality assessment scheme for transfusion medicine in Korea (2017). J Lab Med Qual Assur 2018;40:9-20.

2. De Weers M, Tai YT, van der Veer MS, Bakker JM, Vink T, Jacobs DC, et al. Daratumumab, a novel therapeutic human CD38 monoclonal antibody, induces killing of multiple myeloma and other hematological tumors. J Immunol 2011;186:1840-8.

3. Hannon JL, Clarke G. Transfusion management of patients receiving daratumumab therapy for advanced plasma cell myeloma. Transfusion 2015;55:2770.

4. Chapuy $\mathrm{Cl}$, Nicholson RT, Aguad MD, Chapuy B, Laubach JP, Richardson PG, et al. Resolving the daratumumab interference with blood compatibility testing. Transfusion 2015;55(6 Pt 2):1545-54.

5. Cho J, Nah H, Kim D, Lee E, Kim JS, Kim HO. A case of panagglutination on antibody identification in a multiple myeloma patient receiving daratumumab. Korean J Blood Transfus 2016;27:164-8.

6. Velliquette RW, Aeschlimann J, Kirkegaard J, Shakarian G, Lomas-Francis C, Westhoff CM. Monoclonal anti-CD47 interference in red cell and platelet testing. Transfusion 2019;59:730-7.

7. Bonet Bub C, Castilho L. ID CORE XT as a tool for molecular red blood cell typing. Expert Rev Mol Diagn 2019;19:77783.

8. Finning K, Bhandari R, Sellers F, Revelli N, Villa MA, Muniz-Diaz E, et al. Evaluation of red blood cell and platelet antigen genotyping platforms (ID CORE XT/ID HPA XT) in routine clinical practice. Blood Transfus 2016;14:160-7.

9. Lasalle-Williams M, Nuss R, Le T, Cole L, Hassell K, Murphy JR, et al. Extended red blood cell antigen matching for transfusions in sickle cell disease: a review of a 14-year experience from a single center (CME). Transfusion 2011;51:1732-9.

10. Vichinsky EP, Luban NL, Wright E, Olivieri N, Driscoll C, Pegelow CH, et al. Prospective RBC phenotype matching in a stroke-prevention trial in sickle cell anemia: a multicenter transfusion trial. Transfusion 2001;41:1086-92.

11. Compernolle V, Chou ST, Tanael S, Savage W, Howard J, Josephson CD, et al. Red blood cell specifications for patients with hemoglobinopathies: a systematic review and guideline. Transfusion 2018;58:1555-66.

12. Lee HJ, Shin KH, Kim H, Jeong S, Kong SG, Kim HH. A case of sickle cell anemia with a lack of high frequency red blood cell antigen. Korean J Blood Transfus 2018;29:188-93.

13. Daniels G, Finning K, Lozano M, Hyland CA, Liew YW, Powley T, et al. Vox Sanguinis International Forum on application of fetal blood grouping. Vox Sang 2018;113:e26-35.

14. Bachegowda LS, Cheng YH, Long T, Shaz BH. Impact of uniform methods on interlaboratory antibody titration variability: antibody titration and uniform methods. Arch Pathol Lab Med 2017;141:131-8.

15. Yang JJ, Chung Y, Kim H, Ko DH, Hwang SH, Oh HB. Retrospection of anti-blood group antibody proficiency testing data using the geometric mean and standard deviation. Am J Clin Pathol 2020;153:530-6. 